\title{
Being There: Establishing Instructor Presence in an Online Learning Environment
}

\author{
Ozgur Ekmekci ${ }^{1}$ \\ ${ }^{1}$ School of Medicine and Health Sciences, The George Washington University, USA \\ Correspondence: School of Medicine and Health Sciences, The George Washington University, Washington DC, \\ 20037, USA. Tel: 202-994-1623. E-mail: ekmekci@gwu.edu
}

Received: December 13, 2012 Accepted: January 4, 2013 Online Published: January 25, 2013

doi:10.5539/hes.v3n1p29

URL: http://dx.doi.org/10.5539/hes.v3n1p29

\begin{abstract}
The purpose of this essay is to critically examine course structure and the role it may play in improving teaching presence in an asynchronous online learning environment. The examination is grounded in experiential learning; adult learning principles; case-based and problem-based learning methods; and peer reviews. The discussion is concluded with a proposed course structure and a learning intervention model that might be used to enhance and strengthen teaching presence for instructors engaged in asynchronous online education.
\end{abstract}

Keywords: asynchronous online education, teaching presence, learning model, course design, adult learning

\section{Introduction}

Do students really know that their instructors are there for them? How can instructors be entirely certain how students perceive their presence, especially in asynchronous online teaching environments, where the instructor's physical presence is rather limited? The purpose of this essay is to critically examine course structure and the role it may play in improving teaching presence in an asynchronous online learning environment.

Based on its rapid adoption over the past decade, it would be fair to say that online education is no longer considered a novelty. Online education has grown significantly since the turn of the century, largely due to its ability to offer convenient access, asynchronous participation, and a favorable benefit-cost ratio for students and institutions alike (Allen \& Seamen, 2008). This format for learning and teaching has become a defining element of our present social system (Capra, 2011), where institutions of higher education are offering more and more online courses each year in response to student demand. It is estimated that about $90 \%$ of higher education institutions provide some form of online instruction (Collapy \& Arnold, 2009). As a result, an increasing number of higher education institutions are integrating online learning as a strategic component of their organizational vision (Sheridan \& Kelly, 2010). According to a recent study conducted by the Sloan Consortium (Allen \& Seaman, 2011), the growth rate for online enrollments $(10 \%)$ by far exceeded the growth in the overall higher education student population $(2 \%)$ in the United States, which indicates a continuing shift towards online education. Based on the same study, it is estimated that $31 \%$ of students enrolled in higher education take at least one course online. Findings of the study also indicate that online education is an integral part of long-term strategy for over $65 \%$ of higher education institutions, as student satisfaction for online course offerings is at the same level as face-to-face course offerings.

While this growth is promising, institutions offering online education have to deal simultaneously with increasing demand and higher rates of failure or withdrawal (Aragon \& Johnson, 2008). According to research, this challenge is somewhat grounded in the very nature of online education, which - compared to face-to-face instruction - may be more dependent on instructor behavior and meaningful interactions between students and their instructor (Nishikant, 2009). In particular, students enrolled in asynchronous online programs - a learning environment, consisting of networks of people, which "combines self-study with substantial, rapid asynchronous interactivity with others" to allow "anytime-anywhere learning" (Bourne, Mayadas, \& Campbell, 2000, p.63) often have to expend greater energy to manage their time effectively and sustain their motivation in the absence of a live instructor (Brophy, 2010).

To address this challenge, many institutions are turning to technology to enhance the learning environment without jeopardizing academic rigor and quality (Instructional Technology Council, 2010). Although technology 
can strengthen connections established between students and the instructor (Smith \& Caruso, 2010) (e.g., by offering audio, video, and text channels through which instructors can offer a multi-dimensional delivery platform (Miller, 2011) less than $1 / 4$ of instructors use audio or video-based media on a regular basis in their online courses (Smith \& Caruso, 2010). This ratio may be considered low, especially since it has been suggested that audio feedback in an asynchronous learning environment is associated with the perception that instructors care more about the students (Ice, Curtis, Phillips, \& Wells, 2007) and that many students typically use technology at a much more advanced level in their daily lives (Prensky, 2005).

Despite the level of technology used, an asynchronous learning environment requires that "people learn at various times, and not necessarily all at the same time and in the same place" (Moore, Bourne \& Mayadas, 2005, p. 1614) and usually in the physical absence of an instructor. Furthermore, since most instructors teaching in asynchronous environments plan and conduct their courses from a distance (Duncan \& Barnett, 2009), this limited visibility may adversely affect the quality of learning (Bliss \& Lawrence, 2009; Garrison \& Cleveland-Innes, 2005; Garrison, Cleveland-Innes, \& Fung, 2010), should students form a perception that the instructor is not there with them (Herbert, 2006; Morris, 2009; Tello, 2007). In most cases, students' perception of an invisible instructor often leads to withdrawal from the course (Tello, 2007).

Hence, it is crucial for the instructor to structure and conduct facilitated discourse (Mandernach, Gonzales, \& Garrett, 2006) in an asynchronous online learning environment in order to engage students (Eom, Wen, \& Ashill, 2006; Morris, 2009). Such engagement relies on the ability of the instructor to create frequent opportunities for social interaction, provide clear and unambiguous instructions, design attainable, yet challenging assignments, assemble rich course content, and provide timely feedback (Palloff \& Pratt, 2003). These role expectations support the seminal definition of teaching presence, which is "the design, facilitation, and direction of cognitive and social processes for the purpose of realizing personally meaningful and educationally worthwhile learning outcomes" (Anderson, Rourke, Garrison, \& Archer, 2001, p. 5), developed within the broader context of the community of inquiry framework (Garrison, Anderson, \& Archer, 2000). Taking into account the role of the instructor and considering the impact of teaching presence on learning outcomes for students in an asynchronous learning environment, perhaps the greatest challenge for instructors offering such courses may be to critically examine the way these offerings are structured and delivered.

\section{Teaching Presence Examined through the Lens of SoTL}

Before proposing a way to critically examine the way course offerings are structured and delivered in an asynchronous learning environment, it might be useful to initially ground the discussion in the scholarship of teaching and learning (SoTL). While there are slight variations in the way SoTL is interpreted across the globe (Quinnell, Russell, Thompson, Marshall, \& Cowley, 2010), the notion generally refers to the need for academics involved in teaching to apply the same rigor of scholarly criteria they employ in their research, when they teach related material from the discipline in which they are considered experts (Boyer, 1990). Although the objective of this paper is not to conduct an in-depth review of literature on SoTL, a brief discussion of some select concepts, such as experiential learning; adult learning principles; case-based and problem-based learning methods; and peer reviews, is likely beneficial, since each has the potential to impact an instructor's ability to design, facilitate, and direct "cognitive and social processes for the purpose of realizing personally meaningful and educationally worthwhile learning outcomes" (Anderson, Rourke, Garrison, \& Archer, 2001, p. 5) in an asynchronous learning environment.

\section{Experiential Learning}

Kolb's experiential learning model (1984) - where the instructor constructs reflection-based theories as to what works (and what doesn't) in the classroom and shares outcomes with colleagues, which then ultimately trickles back into the way teaching is practiced in a particular discipline - has since become the foundation for advancing the body of knowledge in SoTL (Null, 2000). Most importantly, SoTL "promotes inquiry into the learning and teaching process" (Benander, 2009, p. 36) and its effectiveness greatly relies on instructors' ability to observe the learning process and critically examine their roles within the experiential learning cycle (Martin, Benjamin, Prosser, \& Trigwell, 1999). Such an examination cannot be complete without considering how teaching presence is constructed (by the instructor) and how it is perceived (by the students). 


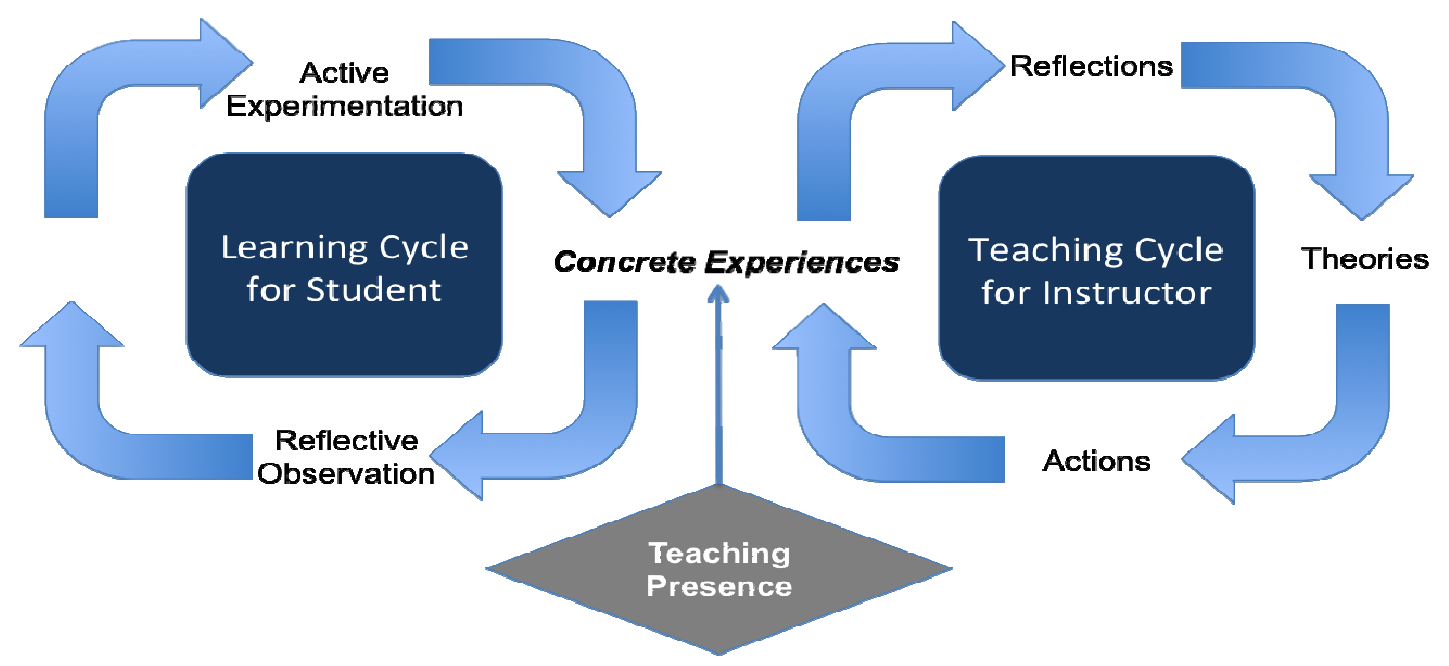

Figure 1. Teaching presence: integrator of learning and teaching cycles [Adapted from Kolb's Learning Model (1984)]

As Figure 1 illustrates, teaching presence plays a pivotal role in the way concrete experiences are shaped for both the instructor and the learner in an asynchronous online learning environment, where the student and the instructor hardly ever share the same space and time. According to Kolb's learning model (1984), concrete experiences taking place in the virtual classroom constitute an asynchronous - yet shared - component that becomes part of the experiential learning cycle for the student, as well as the teaching cycle for the instructor. In other words, teacher presence - or the perception of it - has the potential to directly influence the way the instructor teaches and the way the student learns.

Therefore, when creating such presence, the instructor's main focus should be to act as an enabler of dialogue, reflection, and quality (Lawler \& King, 2003) - someone who ensures that students are engaged in self-directed and reflective learning, in addition to reviewing recorded lectures (Merriam, 2001), while actively managing the asynchronous learning environment. The instructor should allow learners, who bring with them a wealth of life experience, to apply existing knowledge in their fields of study, and produce new and meaningful contributions through research and practice of their own. As proposed by Garrison et al. (2000), "teaching presence is essential in balancing cognitive and social issues consistent with intended educational outcomes' (p. 101) whereby practical inquiry "based upon experience" (p. 98) becomes the framework for transforming practice.

\section{Adult Learning Principles}

Adult learning theory focuses on how adults undergo behavioral changes as a consequence of creating new meanings from their existing experiences (Dewey, 1933; Hergenhahn, 1988; Maples \& Webster, 1980). Andragogy, defined as "the art and science of helping adults learn" (Knowles, 1980, p. 43), emerges as the most prominent model of adult learning (Merriam \& Caffarella, 1999). Andragogy proposes that adult learners prefer to structure their own learning activities, link their learning to actual life experiences, participate in developmental tasks that enhance their social roles, benefit from learning perspectives that are problem-based in the present moment, rather than ones that are subject-based in the future, and are better motivated by intrinsic factors, as compared to extrinsic ones (Knowles, 1980).

In addition, critical reflection (Freire, 1970; Mezirow, 1998), which involves acting on one's newly acquired insights and then critically reflecting on such actions allows adult learners to question the consequences of actual and potential outcomes. The cognitive process of critical thinking is essentially comprised of specific phases through which adults become aware of and describe a problem, formulate alternative ways of dealing with the issue at hand, choose the solution that seems to present the best fit, and finally transform perspectives to integrate the new way of thinking into their cognitive framework (Garrison, 1991; Brookfield, 1995).

Therefore, it is important for anyone teaching adult learners in asynchronous online programs to create a learning environment that is comfortable and non-threatening, is designed around learners' needs, builds and enhances learners' self esteem, encourages active and self-directed participation, acknowledges and utilizes learners' past experiences, allows learners to monitor progress towards set objectives, and - most importantly - promotes 
critical thinking (Goodlad, 1994, 1997; Knowles, 1970, 1973). As proposed by Garrison et al. (2000), establishing a "process that is challenging and stimulating is crucial to creating and maintaining a community of inquiry" (p.101), since "critical thinking is the integration of deliberation and action" (p. 98).

\section{Case-Based and Problem-Based Learning Methods}

Among the many different learning approaches that have emerged to date, two seem to stand out as the most effective (McBurney, 1995), in terms of allowing students to become discerning consumers and producers of knowledge: the case-based method and the problem-based learning (PBL) method. The former allows students the opportunity to investigate and discuss real-life problems from a number of different perspectives, without necessarily asking the students to find a particular solution. Conversely, the latter incorporates elements of experiential learning to promote self-directed learning aimed at increasing motivation, retention, and critical reasoning (Ball \& Pelco, 2006) by challenging students to solve real-world problems.

McBurney (1995) suggests that having students work on real problems presents "an excellent vehicle for teaching critical thinking" (p. 37), whereby problems constitute a source of motivation; the emphasis is on utilizing content rather than obtaining it; and learning takes place through the formulation of thoughts in narrative form (Kurfiss, 1988). Research suggests that teacher presence rises over time in asynchronous PBL environments (Kamin, Deterding, Younger, \& Wade, 2006). Therefore, students should work on topics that are grounded in their own lives - a rich and personal context that allows them to make current, relevant, and meaningful connections. Any work that students are being asked to do that does not possess such connections will likely feel uninspiring and hollow. As proposed by Garrison et al. (2000), "purposeful thinking and acting are essential to the educational process" (p. 98) and establishing a teaching presence that facilitates "the resolution of the dilemma or problem" (p. 98) is at the heart of experience-based practical inquiry.

\section{Peer Reviews}

It is known that asking students to review and discuss each other's work leads to an increase in students' engagement (Ball \& Pelco, 2006). A formal peer review allows students the opportunity to assess each other's work and thus creates a more positive learning experience (Ledman, 2003; Topping, 1998), especially given that student satisfaction and retention is positively associated with the degree of interaction students have with their peers (Bedi 2008; Mandernach, Dailey-Hebert, \& Donnelli-Sallee, 2007).

However, the task of integrating peer reviews demand special consideration. Grouping a number of students together and asking them to comment on one another's work may not lead to desired outcomes, unless the instructors diligently design, develop, and communicate both structure and expected outcomes to students in advance (Chen, Wang, \& Hung, 2009; Wang \& Chen, 2008). This preliminary work constitutes another argument for the need to establish strong teaching presence in an online environment through a structured and systematic approach. As proposed by Garrison et al. (2000), effective teaching presence demands that the role of the instructor include "creating an effective group consciousness for the purpose of sharing meaning, identifying areas of agreement and disagreement, and generally seeking to reach consensus and understanding" (p. 101).

\section{Improving Teaching Presence through Course Structure}

The role of the instructor in enabling online learners' success has been deemed critical (Nishikant, 2009), yet instructors engaged in asynchronous online teaching are not as clear as their colleagues teaching in face-to-face classroom settings - especially when it comes to understanding how their presence is perceived by their students. To address this challenge, a 15-week course structure may be proposed for instructors teaching in an asynchronous learning environment. The proposed structure is grounded in the systematic and modular development of a term paper throughout the duration of the semester, in addition to incorporating a sequential flow of weekly activities. 


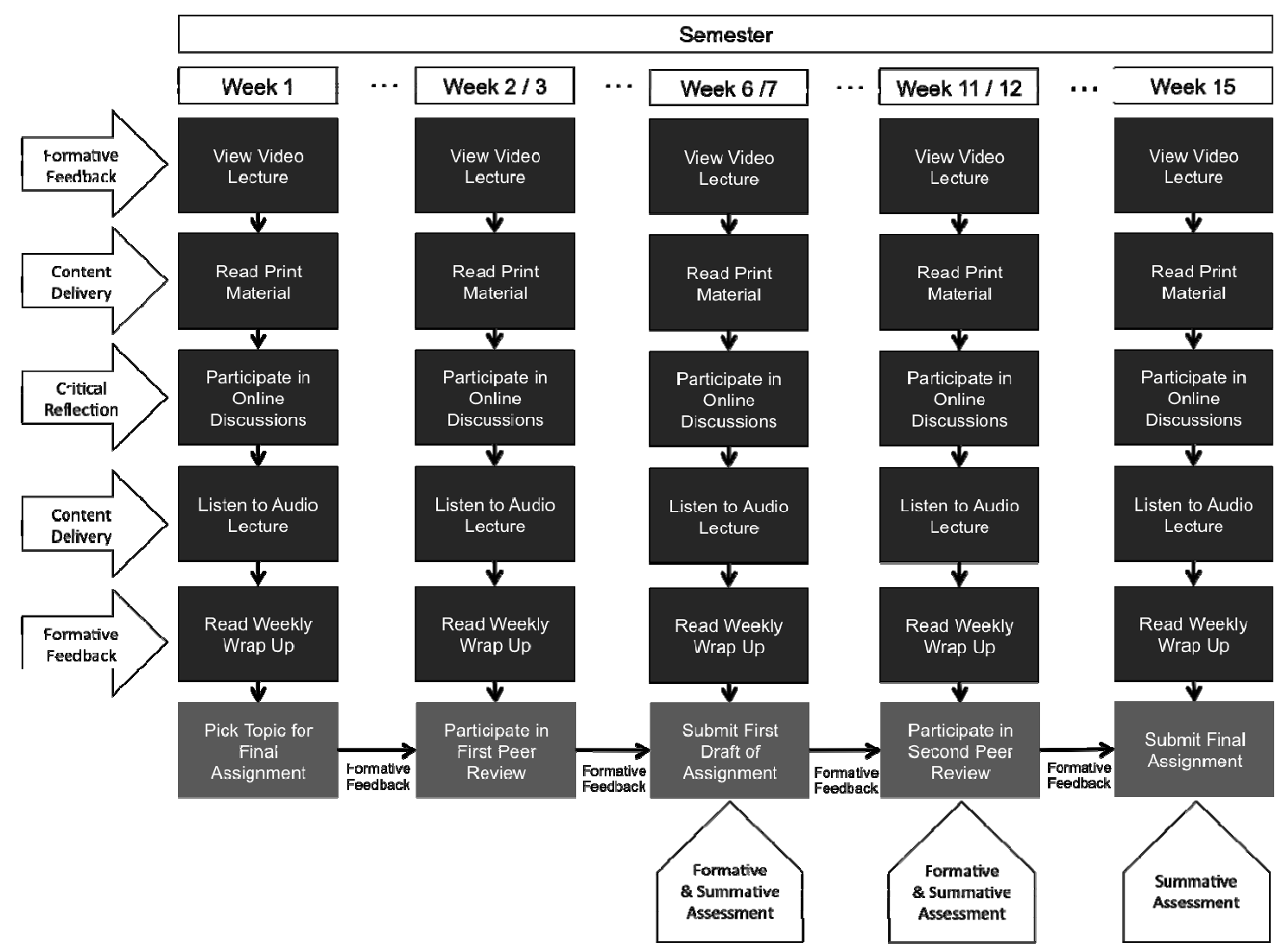

Figure 2. Course structure for a 15 -week semester

Figure 2 illustrates the basic structure and flow for such a course that might be typically taught during a 15 -week semester. Classes could be set up as part of a weekly cycle in which students are asked to view a video lecture, where they: receive formative group feedback regarding assignments and progress in the course; read print material through which they learn content; participate in online discussions, where they employ critical reflection to take a position and defend it, in response to a question relevant to the material they have read; listen to an audio lecture that summarizes the key points of the reading material; and then read the wrap up posted by the instructor in the discussion board, through which they get to think about additional insights. The video lectures and weekly wrap up postings could be very effective tools to communicate formative assessment to students.

While the weekly cycles repeat throughout the semester, students could simultaneously work on their term papers. They could pick a topic during the first two weeks and conduct a peer review right after that to receive formative assessment from their colleagues. Then, around week six or seven, students could be asked to submit the first draft of their term paper, for which they receive formative and summative assessment from the instructor.

After receiving this assessment, students could continue working on their term paper, incorporating what they have learned in class, as well as the feedback they have received from their colleagues and their instructor. The instructor could hold a second peer review around week eleven or twelve to allow students to receive another round of formative feedback from their colleagues and the instructor. Feedback and critical reflection could be designed to help students polish and finalize their term paper. The semester would then end when students submit their term paper and receive summative assessment from the instructor regarding their overall performance in the course.

One of the most crucial elements of this process is likely to be the peer review because of its power to bring together many of the adult learning principles. The peer review activity could be structured employing a role-playing format - which would enable the students to be more critical and constructive in their reviews, without being terribly concerned about offending their colleagues. For example, students could be asked to be the president of a major foundation, reviewing grant proposals for funding or the senior editor of a journal, reviewing research proposals for publication. As part of their role, each student could review the proposals of the two or three other colleagues in small groups and write each one a single-page, double-spaced letter informing 
the applicants of the reviewer's decision, based on the merits of the proposal, along with a brief explanation of why (or why not).

There is one other aspect of an asynchronous online learning environment that deserves special consideration. Since instructors and students hardly ever get together in the same space and time, there is a need to close the gap that separates the students from the instructor. This is where the use of technology becomes important, by allowing the instructor to - through personal communications that transcend space and time - develop autonomous, self-directed, engaged, confident, discerning, and accountable learners.

As part of such communications, the instructor could record and post weekly video lectures to provide collective feedback and guidance, in addition to the individual level feedback provided to each student on their written assignments. While video recordings may be used to transition students from one week to the other by providing a brief recap of what they have accomplished in the past week and what they will be aiming to accomplish in the week ahead - often taking the time to (re)emphasize upcoming assignment requirements, audio recordings may also be used to supplement the written content for the course. This medium may be specifically used to summarize weekly readings, after students have read the assigned readings and have discussed the topics in the discussion forums. Such recordings should give them a sense of closure by listening to the instructor highlight key points that might be worth a second look and further enhance the strength of perceived teaching presence.

\section{Designing an Asynchronous Learning Intervention with Built-in Teaching Presence}

In general, teaching practices that are recommended for quality education include: creating a strong connection with students; encouraging peer cooperation among students; promoting active learning; providing timely and supportive feedback; communicating high expectations; and crafting personalized development paths grounded in students' work and life experiences (Chickering \& Gamson, 1987; Ritter \& Lemke, 2000). However, none of this changes the fact that - for ultimate success in an asynchronous online environment - the perceived teaching presence needs to be: "positive and friendly, knowledgeable, empathetic, and consistent" (Sheridan \& Kelly, 2010, p. 776). In other words, instructors need to be visible to, engaged with, and caring for the students every step of the way throughout the learning journey on which they embark together.

Creating this type of teaching presence is essentially hard work for many instructors. It is known that instructors who are asked to teach online often note substantial increase in workload (Sammons \& Ruth, 2007). This is especially true with instructors who have not taught in an online environment before (Instructional Technology Council, 2010). Furthermore, as online instructors often work in isolation from colleagues, obtaining and disseminating best practices might be severely limited (Duncan \& Barnet, 2009). While technology might somewhat help instructors connect with their peers using web access, the effort still requires perseverance, discipline, and an initial sense of what does or does not work (Miller, 2011).

Looking ahead, as institutions of higher education continue to expand their online programs, these organizations need to be mindful of the level of support required to help their instructors retain the proper balance between quality and quantity of instruction (Goldman, 2011). Knowing that globalization, technological advancement, and demographic forces will continue to accelerate the development and adoption of this platform (Zhang \& Goel, 2011), instructors engaged in asynchronous online education will continue facing challenges to create the level of connectedness students desire - a bond that can only come through strong(er) teaching presence (Palloff \& Pratt, 2003; Pawan, Paulus, Yalsin, \& Chang, 2003; Swan, Richardson, Ice, Garrison, Cleveland-Innes, \& Arbaugh, 2008).

Students' perceptions of teaching presence depend on "posting regularly to the discussion board, responding in a timely manner to e-mail and assignments, and generally modeling good online communication and interactions" (Palloff \& Pratt, 2003, p. 118) and are greatly influenced by "the design, facilitation, and direction of cognitive and social processes for the realization of personally meaningful and educationally worthwhile learning outcomes" (Anderson, Rourke, Garrison, \& Archer, 2001, p. 5). Therefore, an instructor can create a strong presence to the degree that he or she can "pay particular attention to the communicative aspects" (Sheridan \& Kelly, 2010, p. 767) of the role.

One of the ways to build teaching presence into an asynchronous learning intervention might be to follow a model, as illustrated in Figure 3, where the fundamental questions that should inform and guide the instructor's actions, are plotted along the timeline that defines the scope of the learning activity. The four major phases of this model, along with the key questions that define teacher presence in each one of these phases may be summarized as follows:

Phase I: Define Measurable Learning Objectives

What do I want to change, for whom, by how much, and by when? In other words, what will success look like? 
By asking this question, the instructor will be able to contemplate and quantify the envisioned type of change, its scope (in terms of breadth, depth, and timeline), and the level at which change is to take place (i.e., individual, organizational or societal) - which will help ability to monitor progress against objectives.

Phase II: Plan Learning Intervention

How will I change what, for whom, by how much, and by when? In other words, how will I achieve success? By asking this question, the instructor will more easily identify learners, select content, develop materials, design delivery method, construct learning environment, and develop delivery schedule.

Phase III: Design Learning Evaluation

How will I know what I am changing, for whom, by how much, and by when? In other words, how will I monitor progress against set objectives that define success?

By asking this question, the instructor will be able to identify key variables to be measured, decide on methods and frequency for formative and summative assessment, plan delivery format, medium, frequency, and timing of feedback to students, and select statistical methods that will help determine the effectiveness of the intervention.

Phase IV: Implement Learning Intervention and Conduct Learning Evaluation

Has what I wanted to change, for those whom I wanted to change it, actually changed by the amount I had wanted it to change?

By asking this question, the instructor will be able to effectively deliver content, assess learning, provide feedback to students, analyze data using statistical methods to determine how successful the intervention has been.

All four of these questions demand the active engagement of the instructor - and hence strengthen perceived teaching presence - throughout the course of the asynchronous learning intervention, which often requires the use of audio or video material that features the instructor. These four questions also ensure that teaching and learning activities / outcomes are aligned from start to end, as illustrated in the flowchart depicted in Figure 3, where content delivery, content / method revision, learner feedback (both formative and summative), and classroom assessment techniques (CAT) for making mid-course adjustments are all linked to one another and operate in an integrated fashion.

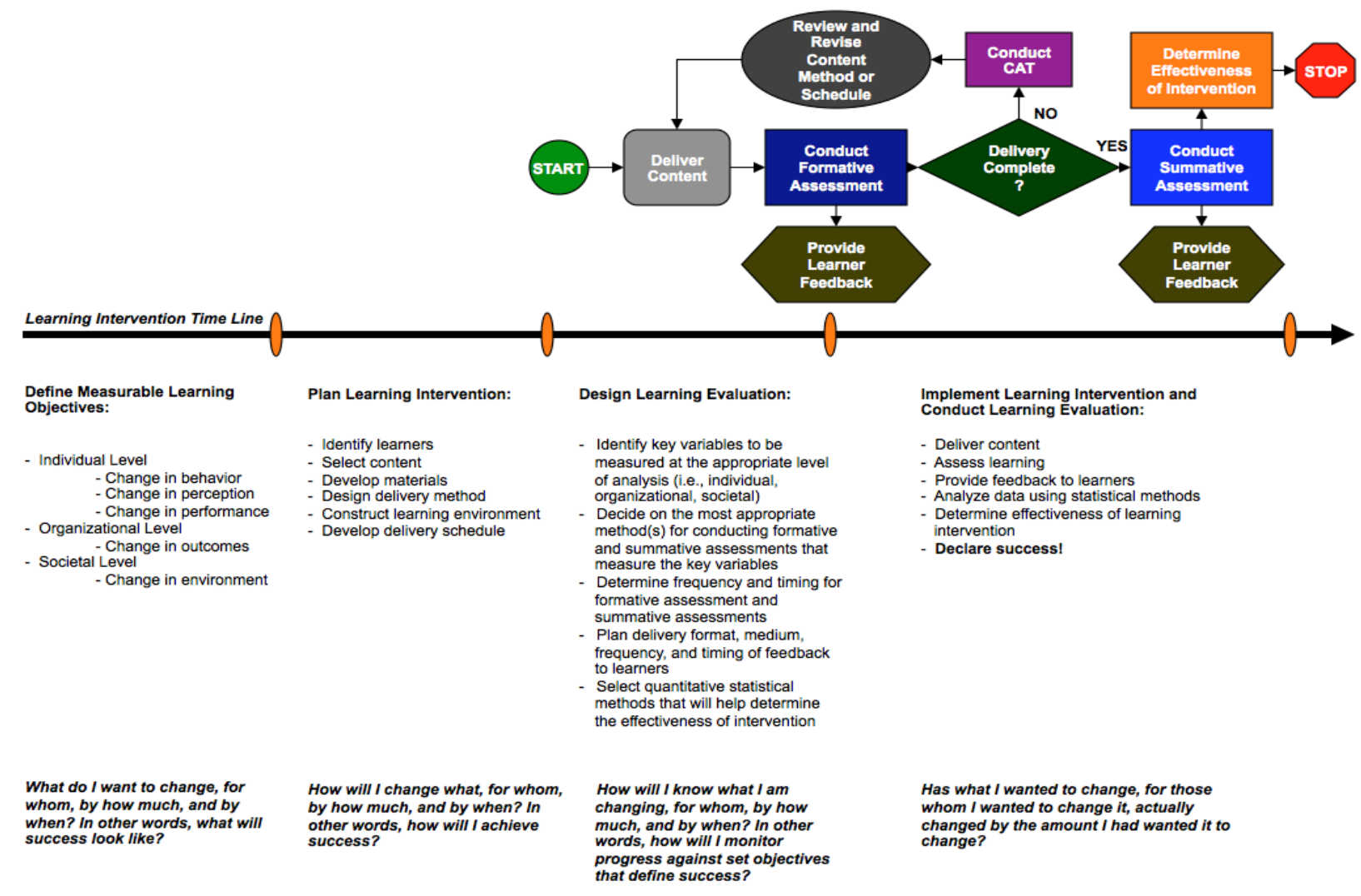

Figure 3. Master plan for designing a learning intervention 


\section{Conclusion}

Given that asynchronous online learning will likely be an integral part of education for the foreseeable future, instructors involved in this medium need to pay special attention to the way their teaching presence is perceived by learners. For all the reasons covered in this discussion, strong teaching presence is a critical component of the learning experience that needs to be planned and managed through critical reflection. Simplifying this presence, as if it merely consists of appearing in generic recorded material, sending mass emails, keeping blogs, or posting superficial comments in discussion boards, is overlooking the importance of the crucial need to align teaching activities and learning activities. Such alignment can only come through a systematic approach, whereby adequate feedback loops - in terms of both formative and summative assessment, classroom assessment techniques, and program evaluation - are built into the learning process that allow those doing the teaching and those doing the learning to make course adjustments, as they mutually travel down the path of the journey they co-create. This co-creation might be the only way to convince learners that there is a being out there - with them - genuinely interested and engaged in how the journey is unfolding and where it will take them in the end. Perhaps the most important question for instructors to ask at each step of this journey is then "What am I doing?"

\section{References}

Allen, I. E., \& Seaman, J. (2008). Staying the course: Online education in the United States. Needham, MA: Sloan-C. Retrieved from http://www.sloan- c.org/publications/survey/pdf/staying_the_course.pdf

Allen, I. E., \& Seaman, J. (2011). Going the distance: Online education in the United States. Needham, MA: Sloan-C. Retrieved from http://sloanconsortium.org/publications/survey/going_distance_2011

Anderson, T., Rourke, L., Garrison, D., \& Archer, W. (2001). Assessing teaching presence in a computer conferencing context. Journal of Asynchronous Learning Networks, 5(2), 1-17.

Aragon, S., \& Johnson, E. (2008). Factors influencing completion and non-completion of community college online courses. American Journal of Distance Education, 22(3), 146-158. http://dx.doi.org/10.1080/08923640802239962

Ball, C. T., \& Pelco, L. E. (2006). Teaching research methods to undergraduate psychology students using an active cooperative learning approach. International Journal of Teaching and Learning in Higher Education, 17(2), 147-154.

Bedi, K. (2008). Best practices of faculty in facilitating online asynchronous discussions for higher student satisfaction. U21Global Working Paper Series, No. 005/2008.

Benander, R. (2009). Experiential learning in the scholarship of teaching and learning. Journal of the Scholarship of Teaching and Learning, 9(2), 36-41.

Bliss, C. A., \& Lawrence, B. (2009). From posts to patterns: A metric to characterize discussion board activity in online courses. Journal of Asynchronous Learning Networks, 13, 1-18.

Bourne, J. R., Mayadas, A. F., \& Campbell, J. O. (2000). Asynchronous learning networks: An information-technology-based infrastructure for engineering education. Proceedings of the IEEE, 88(1), 63-71. http://dx.doi.org/10.1109/5.811602

Boyer, E. L. (1990). Chapter 2: Enlarging the perspective. In E. L. Boyer (Ed.), Scholarship reconsidered: Priorities of the professoriate. The Carnegie Foundation for the Advancement of Teaching.

Brookfield, S. (1995). Becoming a critically reflective teacher. San Francisco, CA: Jossey-Bass.

Brophy, N. (2010). The impact of e-Learning on student engagement. Bright Hub Education. Retrieved from http://www.brighthub.com/education/online

Capra, T. (2011). Online education: Promise and problems. MERLOT Journal of Online Learning and Teaching. 7(2), 288-293.

Chen, D., Wang, Y., \& Hung, D. (2009). A journey on refining rules for online discussions: Implications for the design of learning management systems. Journal of Interactive Learning Research, 20(2), 157-173.

Chickering, A, W., \& Gamson, Z. F. (1987). Seven principles for good practice in undergraduate education. The Wingspread Journal, 9(2), 3-7.

Collapy, R., \& Arnold, J. (2009). To blend or not to blend: Online and blended learning environments in undergraduate teacher education. Issues in Teacher Education, 18(2), 85-101.

Dewey, J. (1933). How we think. Boston: Heath. 
Duncan, H., \& Barnett, J. (2009). Learning to teach online: What works for pre-service teachers. Journal of Educational Computing Research, 40(3), 357-376. http://dx.doi.org/10.2190/EC.40.3.f

Eom, S. B., Wen, J. H., \& Ashill, N. (2006). The determinants of student perceived learning outcomes and satisfaction in university online education: An empirical investigation. Decision Sciences Journal of Innovative Education, 4(2), 215-235. http://dx.doi.org/10.1111/j.1540-4609.2006.00114.x

Freire, P. (1970). Pedagogy of the oppressed. New York: NY: Seabury Press.

Garrison, D. R. (1991). Critical thinking and adult education: A conceptual model for developing critical thinking in adult learners. International Journal of Lifelong Learning, 10(4), 287-303.

Garrison, D. R., \& Cleveland-Innes, M. (2005). Facilitating cognitive presence in online learning: Interaction is not enough. American Journal of Distance Education, 19(3), 133-148. http://dx.doi.org/10.1207/s15389286ajde1903_2

Garrison, D. R., Anderson, T., \& Archer, W. (2000). Critical inquiry in a text-based environment: Computer conferencing in higher education. The Internet and Higher Education, 2(2-3), 87-105. http://dx.doi.org/10.1016/S1096-7516(00)00016-6

Garrison, D. R., Cleveland-Innes, M., \& Fung, T. S. (2010). Exploring causal relationships among teaching, cognitive and social presence: Student perceptions of the community of inquiry framework. The Internet and Higher Education, 13, 31-36. http://dx.doi.org/10.1016/j.iheduc.2009.10.002

Goldman, Z. (2011). Balancing quality and workload in asynchronous online discussions: A win-win approach for students and instructors. MERLOT Journal of Online Learning and Teaching, 7(2), 313-323.

Goodlad, J. (1997). In praise of education. New York, NY: Teachers College Press.

Herbert, M. (2006). Staying the course: A study in online student satisfaction and retention. Online Journal of Distance Learning Administration, 9(4).

Hergenhahn, B. (1988). An introduction to theories of learning (3rd ed.). Englewood Cliffs, N.J.: Prentice Hall.

Ice, P., Curtis, R., Phillips, P., \& Wells, J. (2007). Using asynchronous audio feedback to enhance teaching presence and students' sense of community. Journal of Asynchronous Learning Networks, 11(2), 3-25.

Instructional Technology Council. (2010). 2009 distance education survey results: Tracking the impact of e-learning at community colleges. Washington, D.C.: Instructional Technology Council Press.

Kamin, C. S., O’Sullivan, P., Deterding, R. R., Younger, M., \& Wade, T. (2006). Teaching presence in virtual $\begin{array}{lllll}\text { problem-based learning } & \text { groups. }\end{array}$ http://dx.doi.org/10.1080/01421590600628241

Knowles, M. (1970). The modern practice of adult education: Andragogy versus pedagogy. New York, NY: Association.

Knowles, M. (1973). The adult learner: A neglected species. Houston, TX: Gulf Publishing Company.

Knowles, M. (1980). The modern practice of adult education: From pedagogy to andragogy (2nd ed.). New York: Cambridge Books.

Kolb, D. (1984). Experiential Learning. Englewood Cliffs, New Jersey: Prentice Hall.

Kurfiss, J. G. (1988). Critical thinking: Theory, research, practice, and possibilities (ASHE-ERIC higher education report no. 2). Washington, DC: Association for the Study of Higher Education.

Lawler, P. A., \& King, K. P. (2003). Changes, challenges, and the future. New Directions for Adult and Continuing Education, 98, 83-91. http://dx.doi.org/10.1002/ace.103

Mandernach, B. J., Gonzales, R. M., \& Garrett, A. L. (2006). An examination of online instructor presence via threaded discussion participation. Journal of Online Learning and Teaching, 2(4), 248-260.

Mandernach, J., Dailey-Hebert, A., \& Donnelli-Sallee, E. (2007). Frequency and time investment of instructors' participation in threaded discussions in the online classroom. Journal of Interactive Online Learning, 6(1), $1-9$.

Maples, M., \& Webster, J. (1980). Thorndike's connectionism. In G. Gazda \& R. Corsini (Eds.), Theories of learning. Itasca, IL: Peacock.

Martin, E., Benjamin, J., Prosser, M., \& Trigwell, K. (1999). Scholarship of Teaching: A study of the approaches of academic staff. In C. Rust (Ed.), Improving Student Learning: Improving Student Learning Outcomes (pp. 
326-331). Oxford: Oxford Centre for Staff learning and Development, Oxford Brookes University.

McBurney, D. H. (1995). The problem method of teaching research methods. Teaching of Psychology, 22(1), 36-38. http://dx.doi.org/10.1207/s15328023top2201_11

Merriam, S. (2001). Andragogy and self-directed learning: Pillars of adult learning theory. New Directions for Adult \& Continuing Education, 89, 3-14. http://dx.doi.org/10.1002/ace.3

Merriam, S., \& Caffarella, R. (1999). Learning in adulthood (2nd ed.). San Francisco, CA: Jossey-Bass.

Mezirow, J. (1998). On critical reflection. Adult Education Quarterly, 48(3), 185-198. http://dx.doi.org/10.1177/074171369804800305

Miller, M. V. (2011). A system for integrating online multimedia into college curriculum. MERLOT Journal of Online Learning and Teaching, 7(2), 294-312.

Moore, J. C., Bourne, J. R., \& Mayadas, F. M. (2005). The Sloan Consortium. In C. Howard (Ed.), Encyclopedia of distance learning. Hershey, PA: IGI Global.

Morris, T. A. (2009). Anytime/anywhere online learning: Does it remove barriers for adult learners. In T. Kidd (Ed.), Online education and adult learning: New frontiers for teaching practices. Hershey, PA: IGI Global.

Nishikant, S. (2009). The paradigm shift for adult education: From educational slavery to learning freedom of human brain with synaptic learning. In T. Kidd (Ed.), Online education and adult learning: New frontiers for teaching practices. Hershey, PA: IGI Global.

Null, J. W. (2000). Schwab, Bagley, and Dewey: Concerns for the Theoretic and the Practical. Educational Forum, 65(1), 42-51. http://dx.doi.org/10.1080/00131720008984461

Palloff, R. M., \& Pratt, K. (2003). The virtual student. A profile and guide to working with online learners. San Francisco, CA: Jossey-Bass.

Pawan, F., Paulus, T., Yalsin, S., \& Chang, C. (2003). Online learning: Patterns of engagement and interaction among in-service teachers. Language Learning \& Technology, 7(3), 119-140.

Prensky, M. (2005). Engage me or enrage me: What today's learners demand. Educase Review, 40(5), 61-65.

Quinnell, R., Russell, C., Thompson, R., Marshall, N. \& Cowley, J. (2010). Evidence-based narratives to reconcile teaching practices in academic disciplines with the scholarship of teaching and learning. Journal of the Scholarship of Teaching and Learning, 10(3), 20-30.

Ritter, M., \& Lemke, K. (2000). Addressing 'the seven principles for good practice in undergraduate education' with internet-enhanced education. Journal of Geography in Higher Education, 24(1), 100-108. http://dx.doi.org/10.1080/03098260085171

Sammons, R., \& Ruth, S. (2007). The invisible professor and the future of virtual faculty. International Journal for Instructional Technology and Distance Learning, 4(1), 3-17.

Sheridan, K., \& Kelly, M. A. (2010). The indicators of instructor presence that are important to students in online courses. MERLOT Journal of Online Learning and Teaching, 6(4), 767-779.

Smith, S., \& Caruso, J. (2010). The ECAR study of undergraduate students and information technology, 2010. Boulder, CO: EDUCAUSE Center for Applied Research.

Swan, K. P., Richardson, J. C., Ice, P., Garrison, D. R., Cleveland-Innes, M., \& Arbaugh, J. B. (2008). Validating a measurement tool of presence in online communities of inquiry. ementor, 2(24).

Tello, S. F. (2007). An analysis of student persistence in online education. International Journal of Information and Communication Technology Education, 3(3), 47-62. http://dx.doi.org/10.4018/jicte.2007070105

Wang, Y., \& Chen, V. (2008). Essential elements in designing online discussions to promote cognitive presence: A practical experience. Journal of Asynchronous Learning Networks, 12(3-4), 158-177.

Zhang, P., \& Lakshmi, G. (2011). Is e-learning for everyone? An internal-external framework of e-learning initiatives. MERLOT Journal of Online Learning and Teaching, 7(2), 193-205. 